\title{
BONE DIAGENESIS STUDY OF THE BURIALS FROM THE PEDRA DO ALEXANDRE ARCHAEOLOGICAL SITE, CARNAÚBA DOS DANTAS, RIO GRANDE DO NORTE, BRAZIL
}

ESTUDO DE DIAGÊNESE ÓSSEA DOS SEPULTAMENTOS DO SÍTIO ARQUEOLÓGICO PEDRA DO ALEXANDRE, CARNAÚBA DOS DANTAS, RIO GRANDE DO NORTE, BRASIL

Henry Socrates Lavalle Sullasi

André Luiz Campelo Santos

Sérgio Francisco Serafim Monteiro da Silva

Como citar este artigo:

SULLASI, Henry, S. L.; SANTOS, André, L. C.; SILVA, Sérgio, F. S. M.Bone diagenesis study of the burials from the Pedra do Alexandre archaeological site, Carnaúba dos Dantas, Rio Grande do Norte, Brazil. In: Cadernos do Lepaarq, v. XV, n.30., p. 162-178, Jul-Dez. 2018. 


\title{
Bone diagenesis study of the burials from the Pedra do Alexandre archaeological site, Carnaúba dos Dantas, Rio Grande do Norte, Brazil.
}

\author{
Henry Socrates Lavalle Sullasi ${ }^{\mathrm{a}, \mathrm{b}}$ \\ André Luiz Campelo Santos ${ }^{\mathrm{b}}$ \\ Sérgio Francisco Serafim Monteiro da Silva ${ }^{\mathrm{a}}$
}

\begin{abstract}
The Pedra do Alexandre archaeological site was target of several archaeological campaigns, the bone remains from at least 36 human individuals, and charcoal fragments associated to these burials were among the archaeological findings of the campaigns. The radiocarbon dating provided values between $9400 \pm 90 \mathrm{BP}$ and $2620 \pm 60$ BP. However, attempts to dating the bone remains proved fruitless due to the loss of collagen caused by taphonomic processes. From that finding, this research was initiated to assess the degree of diagenetic alteration of the bone remains from the Pedra do Alexandre archaeological site. FTIR and XRD analyses conducted on 6 random human bone samples from the Site and $\mathrm{pH}$ measurements in correlated sediments have enabled us to conclude that all the analyzed bone remains were extensively degraded by microbial activity, although in different degrees of alteration.
\end{abstract}

\section{Keywords:}

Pedra do Alexandre; Bone diagenesis FTIR; XRD.
Resumo: O sítio arqueológico Pedra do Alexandre foi alvo de várias campanhas arqueológicas, os restos ósseos de pelo menos 36 indivíduos humanos, e os fragmentos de carvão associados a esses enterros estavam entre os achados arqueológicos das campanhas. A datação por radiocarbono forneceu valores entre $9400 \pm 90$ AP e $2620 \pm 60$ AP. No entanto, as tentativas de datar os ossos continuam sendo infrutíferas devido à perda de colágeno causada pelos processos tafonômicos. A partir dessa descoberta, esta pesquisa foi iniciada para avaliar o grau de alteração diagenética dos remanescentes ósseos do sítio arqueológico Pedra do Alexandre. Análises de FTIR e XRD em 6 amostras aleatórias de osso humano do Sítio e medições de $\mathrm{pH}$ em sedimentos relacionados permitiram concluir que todos os remanescentes ósseos analisados foram amplamente degradados pela atividade microbiana, embora em diferentes graus de alteração.

\section{Palavras Chave:}

Pedra do Alexandre; Diagênese óssea; FTIR; DRX.

$\boldsymbol{a}$ Department of Archaeology, Universidade Federal de Pernambuco (UFPE), Avenida Professor Moraes Rego, 1235, 50670-901, Recife, PE, Brazil. E-mail address: henry.lavalle@gmail.com

$\boldsymbol{b}$ Graduate Program in Archaeology, Universidade Federal de Pernambuco (UFPE), Avenida Professor Moraes Rego, 1235, 50670-901, Recife, PE, Brazil. 


\section{INTRODUCTION}

The Pedra do Alexandre archaeological site is a rock shelter located in the municipality of Carnaúba dos Dantas, in the state of Rio Grande do Norte, Brazil. It is one of the sites that constitute the Seridó Archaeological Area, which is comprehended in the states of Rio Grande do Norte and Paraíba (Fig. 1) (Torres, 1995/1996, Martin, 1995/1996, Queiroz and Cardoso, 1995/1996).

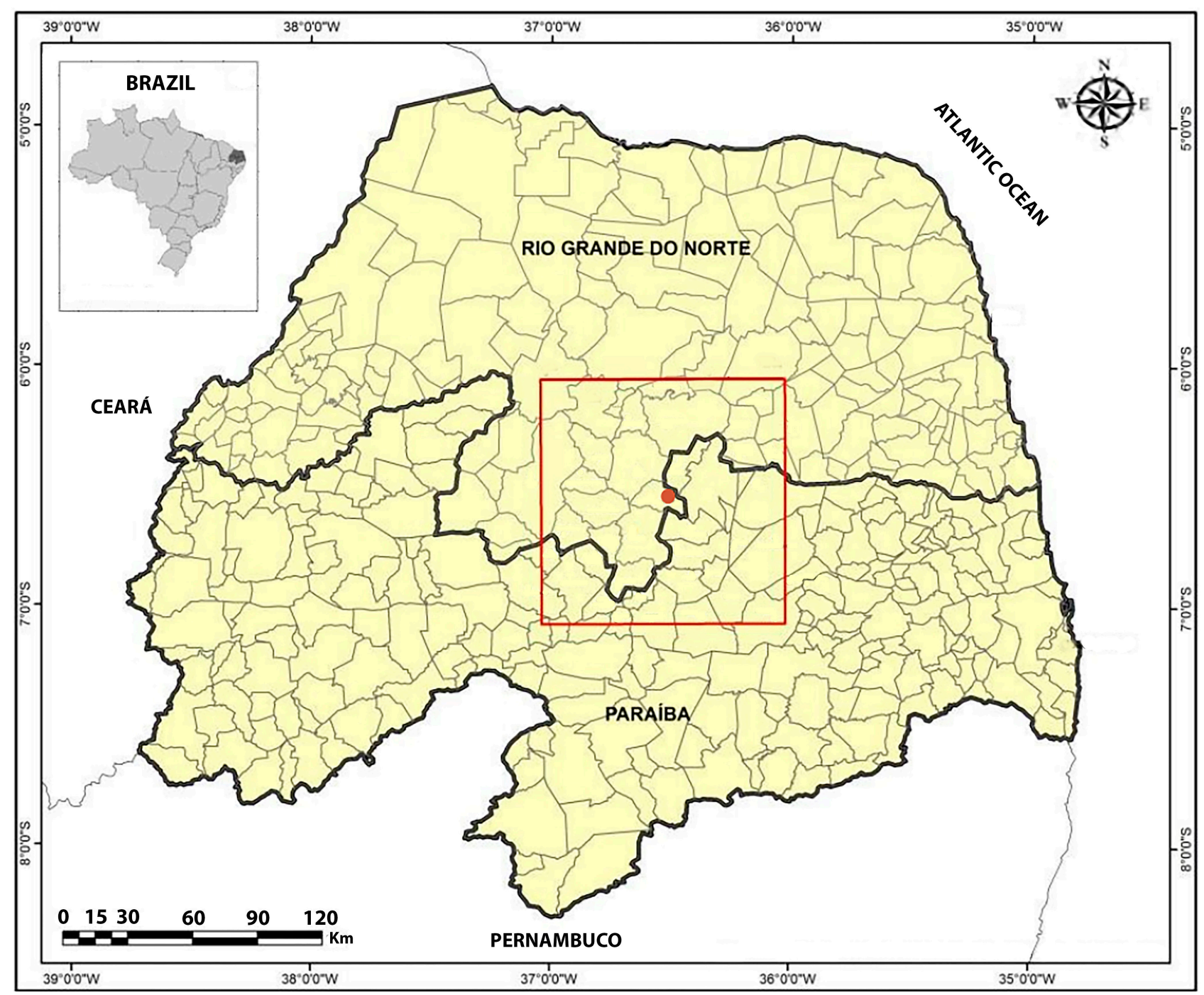

Fig. 1. The Seridó Archaeological Area. Pedra do Alexandre approximate location is indicated by the red dot (Mafra, Martin, Nogueira, 2015, p. 12, adapted).

Between the years of 1990 and 2010, 17 excavation campaigns were conducted on the Site (Mutzenberg, 2007, Martin, 2008, Macedo, 2009). In 2010, after the last archaeological campaign, the skeletal remains of at least 36 human individuals, divided into a total of 31 burials, had been exhumed and can now be found at the Laboratory of Forensic Archaeology and Biology (LABIFOR) of the Federal University of Pernambuco (UFPE). Charcoals from campfires, among other materials and artifacts, such as quartz and flint flakes and a polished axe, were also found (Borges, 2008, Macedo, 2009). In the first half of the 90s, these charcoals were sent to the High Council for Scientific Research (CSIC) of Madrid, Spain, that provided 11 radiocarbon dates associated to 7 of the excavated burials (Table 1). This came to enable the determination of a chronolog- 
ical sequence which spans from $9400 \pm 90 \mathrm{BP}$ to $2620 \pm 60 \mathrm{BP}$ for a not necessarily continuous human occupation in the site (Martin, 1995/1996, 2003, 2008, Martin et al., 2008).

Table 1: Pedra do Alexandre archaeological site radiocarbon dating (Martin, 1995/1996, p. 112, and Queiroz, 2002, p. 270, adapted).

\begin{tabular}{ccc}
\hline Sample & Age (BP) & Associated burials \\
\hline CSIC-1061 & $2620 \pm 60$ & Number 7 \\
CSIC-1053 & $2750 \pm 40$ & Number 9 \\
CSIC-945 & $2860 \pm 25$ & Same depth as Number 9 \\
CSIC-966 & $2890 \pm 25$ & Number 9 \\
CSIC-1054 & $4160 \pm 70$ & Number 2 \\
CSIC-943 & $4710 \pm 25$ & Number 1 \\
CSIC-1060 & $5790 \pm 60$ & Number 6 \\
CSIC-1052 & $6010 \pm 60$ & Depth below the Number 1 \\
CSIC-965 & $8280 \pm 30$ & Number 4 \\
CSIC-967 & $9400 \pm 35$ & Number 3 \\
CSIC-1051 & $9400 \pm 90$ & Same depth as Number 3 \\
\hline
\end{tabular}

However, Mutzenberg (2007) points out that in order to generate a better interpretation of the Site past human occupation it is necessary to conduct absolute and direct dating of all burials, or all the individuals, if possible, by Radiocarbon employing the Accelerator Mass Spectrometry (AMS) instrumentation. According to the mentioned author (2007, p. 117) "due to the constant revolving of the [...] sediments, Radiocarbon dating of associated charcoals may contain errors, leading to inaccurate analyzes".

In the second half of 2011, 4 bone samples from the individuals 10,22, 26 and 27, and a tooth from the individual 29, were chosen by their apparent good condition and sent to the Beta Analytic laboratory to be dated through the use of Radiocarbon AMS technique. However, the application yielded no results since, according to the laboratory, the samples no longer had enough quantities of organic material — collagen — to be dated, i.e., the samples were diagenetically degraded. The basic principle of diagenesis is that when materials are buried they begin to undergo physical and chemical changes caused by their interaction with acidic environments, underground water, minerals and/or even biochemical activity present in the surrounding soil (Goffer, 2007).

Currently, Carnaúba dos Dantas is under the effect of semi-arid climate, with low rainfall, and hyperxerophilic and sub-desert vegetation (Mutzenberg, 2007). The region in which the site is located undergoes a rapid desertification process, and the previously perennial Carnaúba River is less and less abundant. However, approximately 10,000 years ago, which corresponds to the earliest dates obtained in the region related to human occupation, the climatic characteristics of the place were different from those found at the present: the former perenniality of the Carnaúba River would have enabled milder conditions for the prehistoric human occupation of the region (Mutzenberg, 2007, Queiroz, 2002, Martin, 1995/1996).

Given that the samples sent for dating were chosen because-macroscopically - they presented the best state of conservation of all the exhumed individuals, an assessment was conducted to identify which contextual factors at the Pedra do Alexandre archaeological site may have caused the bone diagenesis and the consequent loss of collagen in the samples. 


\section{BONE DIAGENESIS AND RADIOCARBON DATING}

Diagenesis is a set of processes that, under certain burial conditions, can ultimately result in the total physical-chemical conversion of affected materials until they are fully integrated into the stratified sediments (Collins et al., 2002, Hedges, 2002,Shahack-Gross et al. 2003, Shahack-Gross et al, 2004). The most common diagenetic processes are: a) authigenesis, b) bioturbation, c) cementation, d) compaction, e) recrystallization, f) replacement, and g) solution (Goffer, 2007). To understand how the diagenetic processes occur in a bone or tooth, it is important first to understand their composition.

Bone is a composite material consisting of calcium phosphate (inorganic component) precipitated in a collagen matrix (organic component). The concentration of these materials in bone composition varies considerably with age and the type of bone. However, the inorganic component corresponds to approximately $69 \%$ of the bone material, while the organic component corresponds to $22 \%$, and usually the remaining $9 \%$ would be filled by water. The mineral called hydroxyapatite (HA), highly insoluble, is predominant in the bone inorganic component (Pate and Huton, 1988,Mays, 1998). The organic component is composed of proteins, the most abundant being collagen type I (Smith et al., 2005, Weiner, 2010). The debate over the use of human and animal bones for radiocarbon dating is still open, with successes and failures related to bone pre-treatment, the nature of collagen, contamination, burned or calcined bone and the techniques of collagen extraction (Harbeck and Grupe, 2009; Brock et al., 2010;Zazzo and Saliège, 2011; Colonese et al., 2014).

Bone diagenesis generally occurs through three pathways (Collins et al, 2002,Hedges, 2002, Ceccanti et al, 2007). In the first pathway, the slow collagen loss occurs by chemical hydrolysis, resulting in a greater evidencing of the bone porosity. At the same time, these pores are filled with material from its surroundings, which is presumably one of the main mechanisms that lead to the fossilization of bones. The rate at which collagen is lost will depend on the time which the bone remained buried, temperatures to which such material was exposed and the $\mathrm{pH}$ of the soil in which it is buried - it is important to note that both extremes of $\mathrm{pH}$ can cause hydrolysis acceleration. The decay or persistence of the collagen is directly related to its possible transition to a more biodegradable - gelatinous - form, since such transition has an impact on the survival of the organic component. This process is retarded by the presence of the inorganic component and the very tight organization of collagen fibers. However, the factors already mentioned — high temperatures, for example — can accelerate it (Mays 1998, Collins et al., 2002,Hedges, 2002).

The second pathway concerns the changes that affect the inorganic component. In cases of deterioration of the inorganic component, diagenetic processes of dissolution and recrystallization prevail. In addition, for cases of bones that were found above or in the vicinity of groundwater, the hydrology of the region will be a key factor for the persistence of the inorganic component (Collins et al., 2002, Brown and Brown, 2011). However, in acidic soils—i.e., pH $<7$ - some of the bone minerals can be completely dissolved. On the other hand, alkaline or basic soils, i.e. soil with a pH above 7, such as calcareous soils, provide more advantageous conditions for the preservation of the skeletal remains inorganic component (Shahack-Gross et al., 2004,Goffer, 2007). The weathering of minerals present in the soil often results in the generation of ions-in this case cations, i.e., positively charged ions. The acidic $\mathrm{pH}$ of a soil depends mostly on the presence and concentration of hydrogen $\left(\mathrm{H}^{+}\right)$and aluminum $\left(\mathrm{Al}^{+}\right)$cations in the sediment. In alkaline sediments, basic cations replace or are present in greater quantity than aluminum and hydrogen cations (Garrison, 2003). Thus, bone HA is generally more stable and early diagenesis of the skeleton results in HA transformation into more thermodynamically stable phases of recrystallization. Preservation variability reflects the intimate connection between bone composition, environment and geochemistry of the burial site, with recrystallization driven by mineral stabilities, dissolved ions in underground water, site mineralogy, and sediment porosity (Keenan, 
2016).

Various types of bacteria present in the soil are also able to make it acid. This happens when these microorganisms oxidize the sulfur in the sediments producing sulfuric acid, which would be the third pathway by which diagenesis occurs in bone remains. This acid production causes a decrease of the soil $\mathrm{pH}$, which can reach values of about 4 or even lower (Ambrose and Krigbaum, 2003, Shahack-Gross et al., 2004). The microbial deterioration-which also includes the action of fungi-is probably the most common mechanism of bone alteration and can occur quickly after the burial (Binford 1981, Pruvost et al., 2007, Brady et al., 2008). While the chemical deterioration is accelerated in soils with extreme pH or high temperatures, the microbial activity is enhanced in conditions where the soil $\mathrm{pH}$ is initially neutral. The removal of the inorganic component as a result of the soil low $\mathrm{pH}$ allows microorganisms to access and use the collagen as food. The microbial attack is in many aspects similar to the dissolution mechanism — chemical deterioration. However, microbial action is focused on discrete areas of damage also known as microscopic focal destruction (Collins et al., 2002, Hedges, 2002, Ambrose and Krigbaum, 2003, Shahack-Gross et al., 2004; Goffer, 2007).

The alterations caused by bone diagenesis can be detected by techniques that are already widely used in Archaeology, like Raman and Infrared (FTIR) spectroscopies, and X-ray Diffraction (XRD) (Pate et al., 1989, Berna et al., 2004, Zazzo et al, 2012, Sui et al, 2013). These techniques enable the quantification of diagenetic indices both in archaeological and modern bone samples, and once these indices are calculated it is possible to assess the extent of bone diagenesis.

\section{MATERIALS AND METHODS}

\section{Assessing bone diagenesis}

For this assessment, a modern human bone sample and bone fragments obtained from 6 randomly chosen individuals exhumed in the Pedra do Alexandre archaeological site-individuals 2, 15A, 15B, 27, 28 and 29-were analyzed by Fourier Transform Infrared spectroscopy by Attenuated Total Reflectance (FTIR-ATR) and X-ray Diffraction (XRD) techniques at the Department of Chemical Engineering (DEQ) of UFPE. Both analyzes were conducted by DEQ staff. The Department of Anatomy of UFPE provided the modern human bone sample, and its concession followed all the scientific and ethical protocols required by the Department and the University. Before the analysis, all the samples were cleaned in Milli-Q water in an ultrasonic bath to reduce sedimentary contamination. Then, after putting to dry in an oven, the bone samples were crushed, sieved and pulverized in a mortar to create fine particles and subsequently packed into a specific sample holder for the analysis. This pre-analyzes treatment was performed at the Department of Nuclear Energy (DEN) of UFPE by their respective staff.

The XRD technique makes it possible to determine the Crystallinity Index (CI), which is especially important for the study of bone diagenesis as it regards to the amount of inorganic material relative to the amount of organic in the sample analyzed, among other aspects about its mineral phases (crystal sizes, regularity of its crystalline structure etc.). As originally suggested by Hedges et al. (1995), for the CI determination, the full width at half maximum (FWHM) of the diffraction peak (002) was measured (Fig. 2). Thus, the higher the value for the FWHM of the diffraction peak (002), the higher the CI. The mentioned peak was originally chosen because it allows for the achievement of the greatest reproducibility of measurements among the HA peaks (Hedges et al., 1995). Given that the recrystallization process occurs after the loss of collagen in buried bones, the higher the CI, higher is the collagen loss. (Reiche et al., 2002, Stathopoulou et al, 2008, Piga et al, 2009, Abdel-Maksoud, 2010, Beasley et al., 2014). The XRD instrument used was a Bruker D8 DISCOVER, and the diffractrograms were analyzed with the aid of OriginPro $8.5^{\circledR}$ software. 


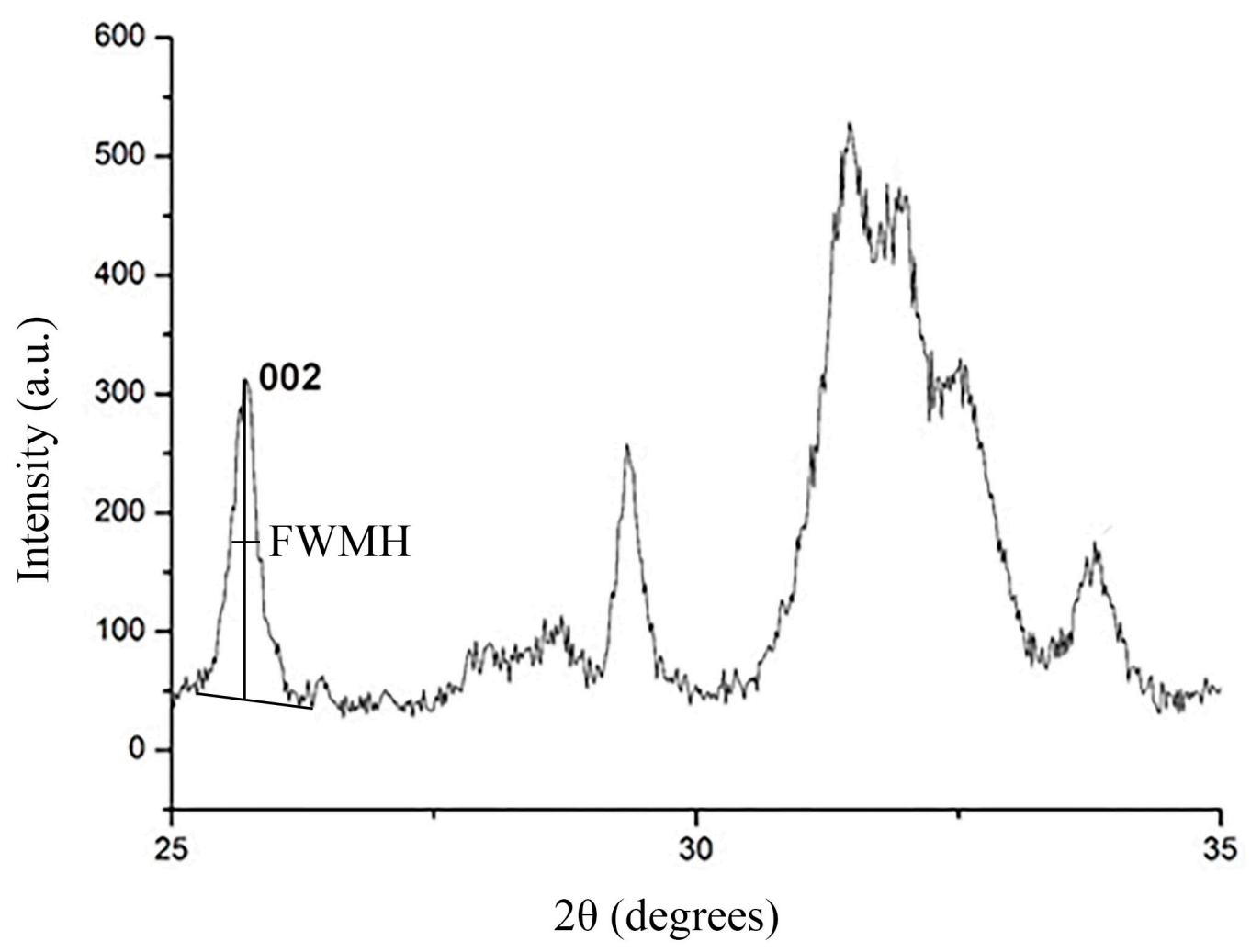

Fig. 2. Detail of a modern bone sample diffractogram showing how the CI was measured in this study.

Alongside the XRD, Fourier Transform Infrared (FTIR) spectroscopy is another technique commonly used in Archaeology for the study of bone diagenesis (Surovell and Stiner, 2001). Such spectroscopy analyzes the interaction between infrared radiation and matter. To achieve this objective, a mathematical algorithm is used, the Fourier Transform, which enables the generation of spectra that, in turn, allows the analysis of molecular structures from materials - collagen and HA included (Beasley et al., 2014, Thompson et al., 2009). From the measuring of some peaks heights present in the FTIR spectra, it was possible to calculate another two diagenetic indices: the IR-SF (Infrared Splitting Factor), an analogous index to the CI, but calculated in FTIR spectroscopies, and the C/P (Carbonate-Phosphate) ratio (Figure 3) (Roberts et al., 2002, Szostek, 2009, Farias, 2013). The calculation of the C/P ratio is particularly important for the study of diagenetic processes that affects the inorganic component as this index regards to the presence of the carbonate $\left(\mathrm{CO}_{3}\right)$ and phosphate $\left(\mathrm{PO}_{4}\right)$ radicals in the sample. Note that the HA is a calcium phosphate and in bone it is presented carbonated (i.e., $\mathrm{HA}+\mathrm{CO}_{3}$ ) (Beasley et al., 2014).

In absorbance mode, the IR-SF is calculated by the sum of two peaks heights approximately located at the bands $560 \mathrm{~cm}^{-1}$ and $600 \mathrm{~cm}^{-1}$ in the spectrum and dividing the result by the height of the "valley" around the band $590 \mathrm{~cm}^{-1}$ (Weiner, Bar-Yosef, 1990, Stiner et al., 1995, Hollund et al., 2012). While the C/P ratio is calculated by the ratio between the heights of the peaks located around $1415 \mathrm{~cm}^{-1}$ and $1030 \mathrm{~cm}^{-1}$ bands (Hollund et al., 2012, Beasley et al., 2014). Prior to both indices calculation, baselines were manually drawn on the bases of the cited peaks to measure their heights (Weiner, Bar-Yosef, 1990). Besides these two indices, the FTIR spectroscopy is also capable of providing a visual indication that aids in the task of evaluating the persistence or absence of collagen in the sample (Beasley et al., 2014). This indication is a prominent or not (in the case of collagen absence) peak located in the bands around $1637 \mathrm{~cm}^{-1}$ and $1655 \mathrm{~cm}^{-1}$ (Weiner, Bar-Yosef, 1990), called Amide I peak (Fig. 3). 


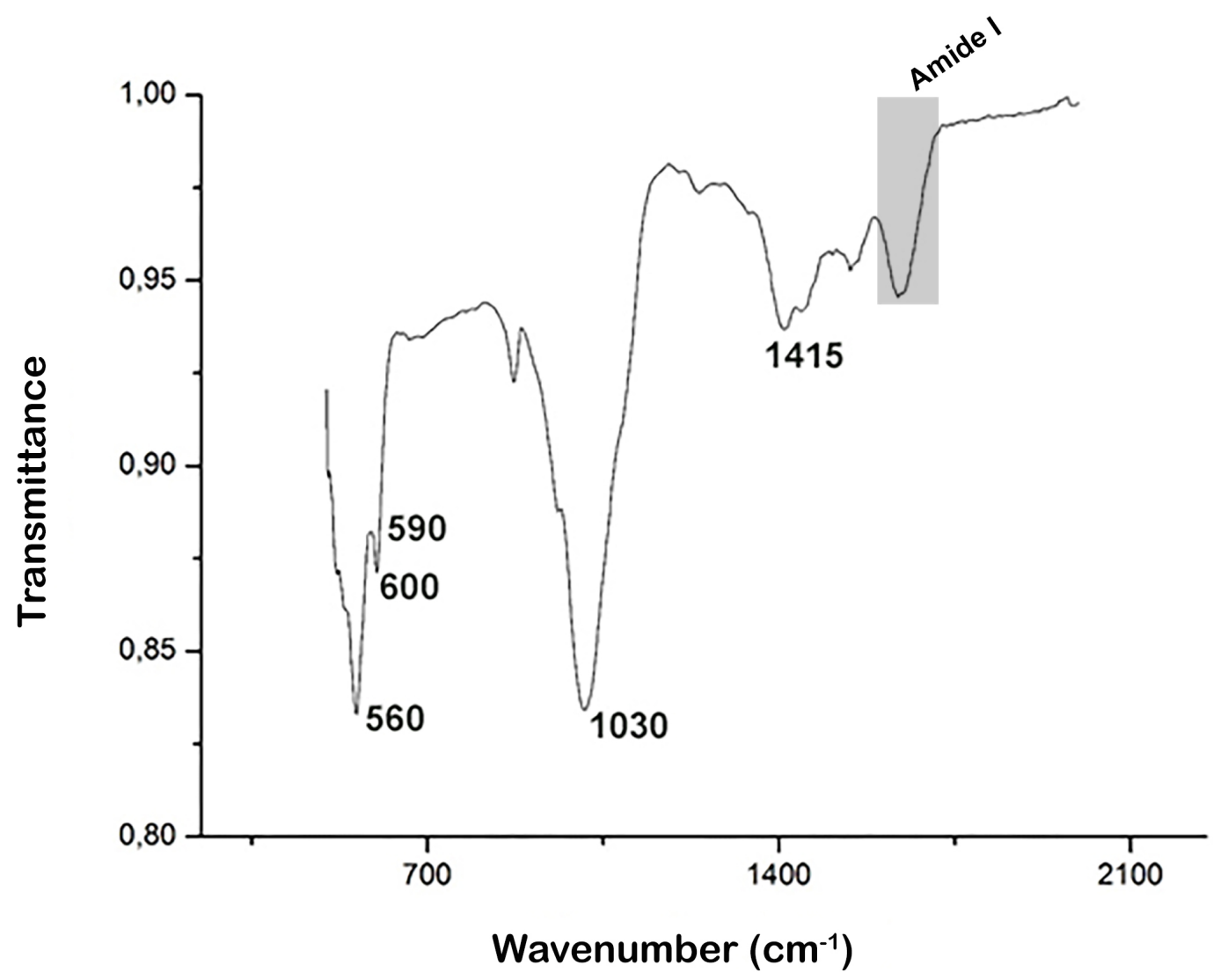

Fig. 3.FTIR-ATR spectrum in transmittance mode of a modern bone sample showing the peaks/valleys used to calculate the IR-SF and C/P ration, and the Amide I peak-in this case, a valley.

The FTIR-ATR spectrometer used was a Bruker TENSOR 27, and the spectra were also analyzed with the aid of OriginPro $8.5^{\circledR}$ software.

\section{Determining the soil pH and composition}

A study on the soil pH and composition of the Pedra do Alexandre archaeological site was also carried out to identify the contextual factors that enabled or not the occurrence of bone diagenesis.

For the measuring of soil $\mathrm{pH}, 10 \mathrm{~g}$ from 6 soil samples_-numbered 544, 555, 1314, 1389, 4431, 4432—associated with the 6bone samples previously presented were subjected to a $\mathrm{pH}$ meter. As suggested in other studies, neutral solutions of the sedimentary samples saturated with water were produced for the $\mathrm{pH}$ analysis (Shahack-Gross et al. 2003,Shahack-Gross et al., 2004,Lage et al, 2006, Lage et al, 2007). Two of the sedimentary samples, 544 and 555, were collected in the same sector (XI) as the bone sample 2; two others, 1314 and 1389, were collected in the same sector (III) as the bone samples 15A and 15B; and the last two, 4431 and 4432, were collected in the same sector (XXXIV) as the bone samples 27, 28 and 29 (Fig. 4).

The classification of the samples $\mathrm{pH}$ was carried out according to the scale for sedimentary $\mathrm{pH}$ suggested by the Natural Resources Conservation Service agency of the United States Department of Agriculture (NRCS-USDA).

In order to enable the identification of the samples mineralogical compositions, from the 6 sedimentary samples available, 3 of them — samples 555, 1389 and 4432, one from each sector-were also analyzed via XRD. The mineral phases identification sand their respective proportions calculations were made possible by the use of the Match!® software. 


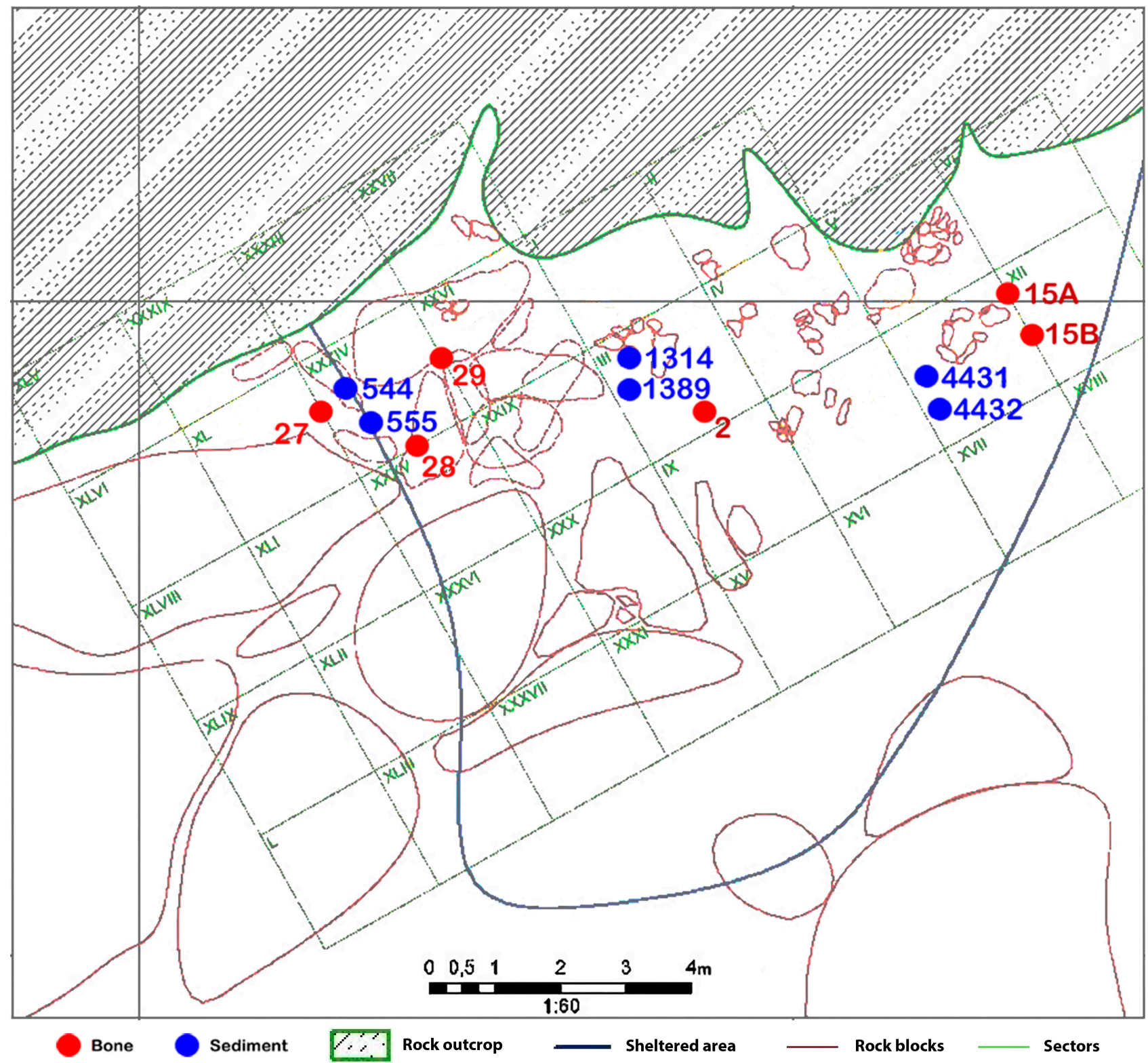

Fig. 4. Localities where the analyzed samples were collected - complete vertical and horizontal lines are geographical coordinate lines (Mutzenberg, 2007, p. 98, adapted).

\section{RESULTS AND DISCUSSION}

From the FTIR-ATR spectroscopy and XRD, it was possible to obtain the characteristic spectra for bone in almost all the samples analyzed - the exception was an absence of the diffractogram for sample 15A. All diagenetic indices obtained for the archaeological samples reported the occurrence of diagenetic changes when compared to the same indices obtained for the modern sample (Table 2). For the modern sample, all the diagenetic indices values obtained were consistent with those reported in the literature (Beasley et al., 2014, Thompson et al., 2009). 
Table 2: Diagenetic indices determined for the bone samples using the FTIR-ATR spectroscopy and XRD techniques

\begin{tabular}{ccccc}
\hline Samples & CI & IR-SF & C/P & 0.37 \\
Modern & 0.31 & 3.17 & 0.11 & 0.03 \\
2 & 0.27 & 4.93 & 0.03 \\
$15 \mathrm{~A}$ & - & 7.25 & 7.15 & 0.13 \\
$15 \mathrm{~B}$ & 0.23 & 4.44 & 0.14 \\
27 & 0.28 & 7.10 & 4.89 & 0.15 \\
29 & 0.26 & 0.24 & 4.15 & \\
\hline
\end{tabular}

The IR-SF values shows that the samples $15 \mathrm{~A}$ and $15 \mathrm{~B}$, obtained from two different individuals exhumed at the same burial, presented the highest levels of diagenetic alteration, closely followed by the sample 28. An extensive recrystallization process that occurred in the bone after the burial can explain these values. IR-SF values of this order also indicate an extensive loss of collagen, with the remaining bone pores now occupied by minerals from the surrounding environment—or newly formed. It is surprising that such scenario was not the same for samples 27 and 29,buried close to sample 28 . The first ones possibly did not suffer as extensive a recrystallization process as the latest. However, this finding can be explained by a possible disparity between their respective periods of burials. If the individual 28 was buried hundreds or even thousands of years earlier than the other two, it is to be expected - but not necessarily have to occur - that its remains present more extensive diagenetic changes.

Featuring a pattern very similar to the IR-SF, the C/P ratio values show that a more extensive diagenetic alteration also reached the inorganic component of the samples 15A and 15B. The C/P values for the burials 27,28 and 29 were very similar. It is important to note that a major change in the inorganic component does not necessarily mean the loss of it, but may indicate the contrary, an increase of their presence - in the case of precipitation of external minerals from the surrounding environment — or simply that there were changes in the proportion of radicals present in the sample. The C/P ratio is a ratio between the amounts of carbonate and phosphate radicals existing in a given bone sample. And in bone the HA, which is a calcium phosphate, is carbonated. Thus, a decreasing value of the $\mathrm{C} / \mathrm{P}$ ratio means that the proportion of phosphate radicals in a given sample is even larger than the ones of carbonate.

Comparing the samples according to the two indices obtained from FTIR-ATR spectroscopy — IR-SF and C/P ratio- the sample 15A is the most diagenetically changed, followed by samples 15B, 28, 2, 29 and 27, in order (Fig. 5). The indices showed a degree of high negative correlation (-0.8) which means that the higher is the IR-SF, lower is the C/P ratio, and vice versa.

As for the prominence of the Amide I peak in the FTIR-ATR spectra, in figure it is possible to see what would be only a trace of this peak in the archaeological samples, demonstrating the low persistence of bone collagen on them when compared with the modern sample (Figure 6).

Similarly to what can be seen for the IR-SF and C/P ratio indices, the CI values for the sample $15 \mathrm{~B}$ is the highest among all the samples analyzed. The measured CI values were consistent with the ones found in other works, including the value for the modern sample (Koch et al., 1997; Reiche et al., 2002; Farlow and Argast, 2006, Abdel-Maksoud, 2010; Rogers et al., 2010). Comparing the CI values with IR-SF ones, the sample 15B shows to be the more diagenetically changed, followed by samples 28, 29, 2 and 27, in order (Fig. 7). These indices also showed a degree of high negative correlation (-0.77). 


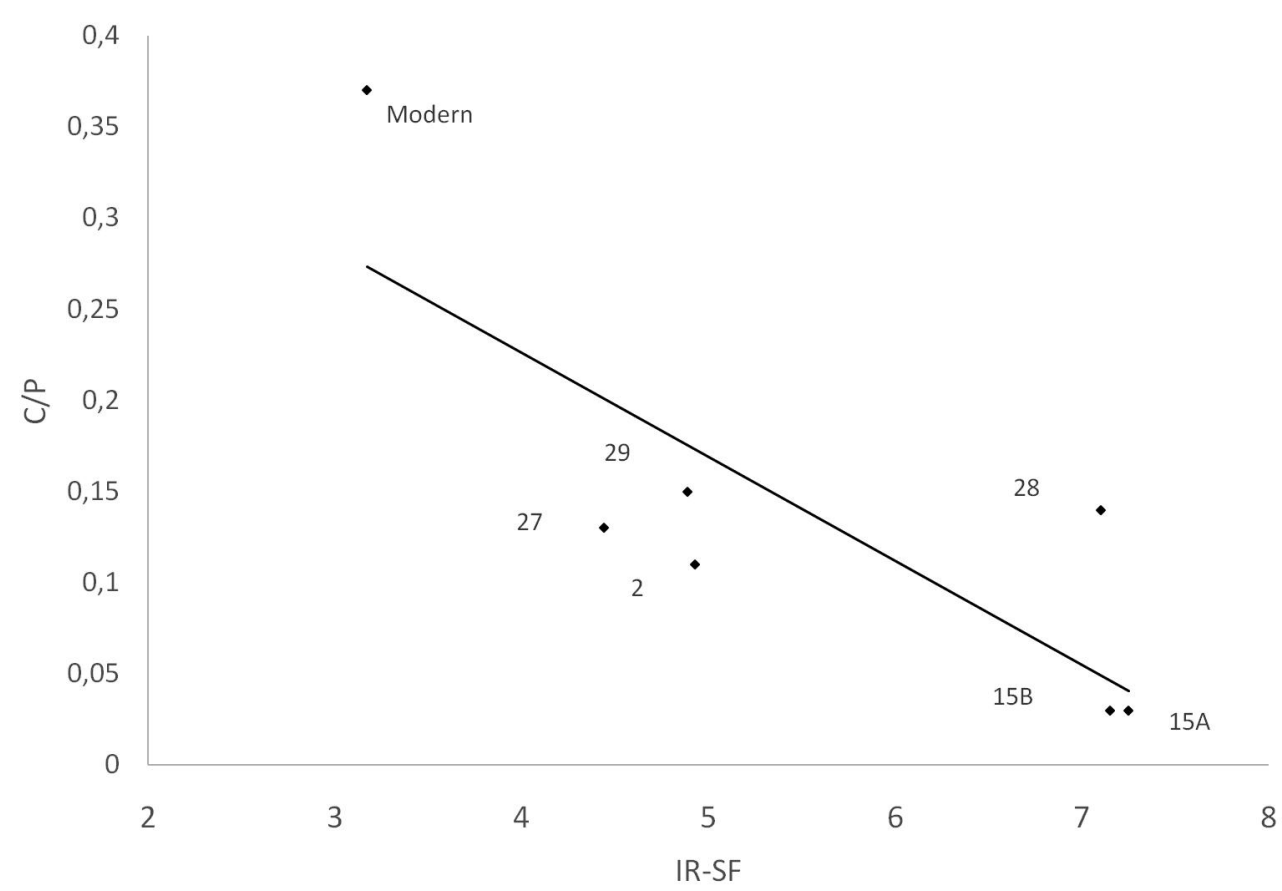

Fig. 5. Correlation between C/P and IR-SF indices of the bone samples analyzed by FTIR-ATR spectroscopy.

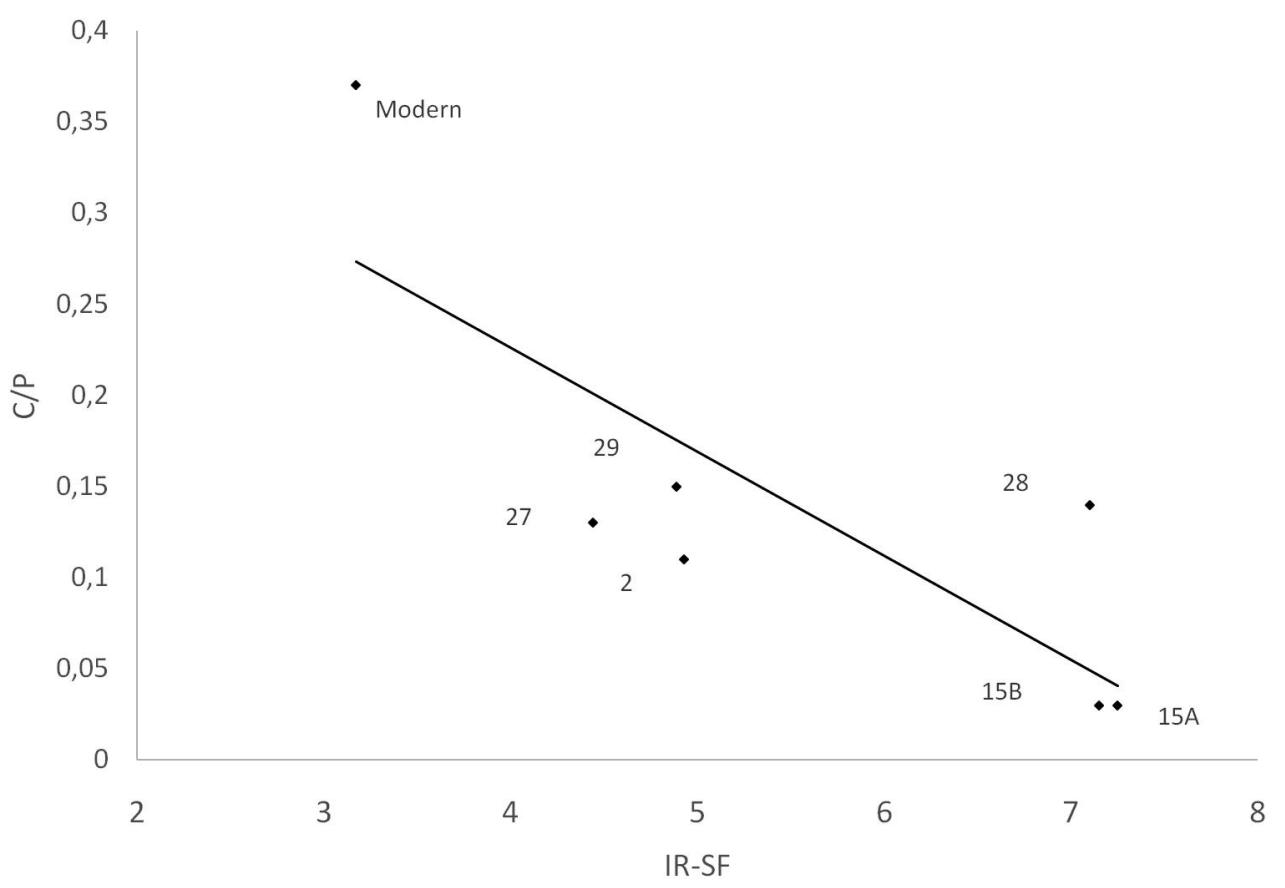

Fig. 6. Comparison between FTIR-ATR spectra from all the bone samples analyzed — only the modern sample spectrum was obtained in transmittance mode, the archaeological spectra were obtained in absorbance mode.

In general, after the discussion of all diagenetic indices determined in this research, it is possible to infer that both bone samples from the burial 15 showed a higher loss of bone collagen, while the other 4 archaeological samples showed fewer extensive losses:

Degree of alteration: $15 \mathrm{~A}>15 \mathrm{~B}>28>(2 \approx 29)>27$ 


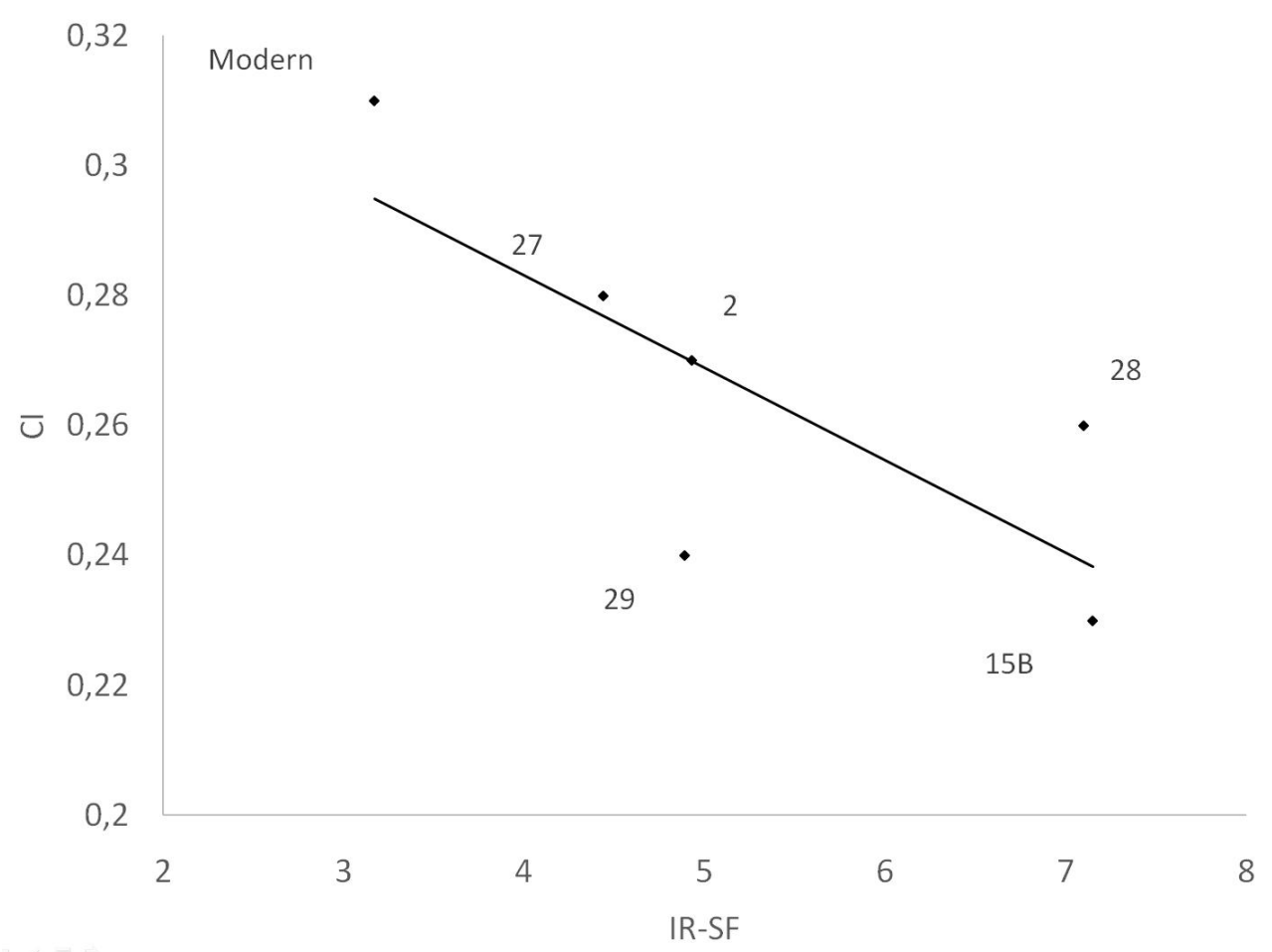

Fig. 7. Correlation between the CI and IR-SF indices obtained from the bone samples analyzed by both XRD and FTIR-ATR spectroscopy.

Such statements relate with the results of the $\mathrm{pH}$ measurements, in which the two sedimentary samples associated with the burial 15 showed the lowest $\mathrm{pH}$ values (Table 3), one slightly acidic and the other slightly alkaline.

Table 3:pH measurement results for the correlated sedimentary samples

\begin{tabular}{ccccc}
\hline Sample & Sector & Correlated bone samples & pH & NRCS-USDA classification \\
\hline 544 & XI & 2 & 8.44 & Moderately alkaline \\
555 & XI & 2 & 8.36 & Moderately alkaline \\
1314 & III & $15 \mathrm{~A}, 15 \mathrm{~B}$ & 7.53 & Slightly alkaline \\
1389 & III & $15 \mathrm{~A}, 15 \mathrm{~B}$ & 6.37 & Slightly acid \\
4431 & XXXIV & $27,28,29$ & 8.24 & Moderately alkaline \\
4432 & XXXIV & $27,28,29$ & 8.68 & Strongly alkaline \\
\hline
\end{tabular}

The three sedimentary samples also analyzed by XRD presented very similar compositions, with minimal variations on the proportions of each mineral phase present. However, something very curious is that the sample 555, which had $\mathrm{pH}$ of about 8.36, i.e., moderately alkaline, also had a small amount of the Brushite mineral in its composition (Table 4).

Table 4: Composition of the associated sedimentary samples

\begin{tabular}{ccccccc}
\hline Sample & Muscovite & Illite & Albite & Kaolinite & Quartz \\
\hline 555 & $33 \%$ & $28.5 \%$ & $15.4 \%$ & $12.5 \%$ & $7.1 \%$ & 3.5 \\
1389 & $35.3 \%$ & $30.4 \%$ & $17.6 \%$ & $13.4 \%$ & $3.3 \%$ & - \\
4432 & $35 \%$ & $30.2 \%$ & $18.1 \%$ & $13.3 \%$ & $3.3 \%$ \\
\hline
\end{tabular}


Brushite is a calcium phosphate as well as HA. However, it is formed in acidic environments by the reaction of phosphate-rich solutions with calcite and/or clay (Anthony et al., 2003). This small amount of Brushite found in only one of the analyzed samples indicates the possibility of this mineral being a product of microscopic focal destruction on the bones buried at sector XI of Pedra do Alexandre archaeological site - as previously stated, various types of bacteria present in the soil are able to make it acid (the third pathway by which diagenesis can occur).

In terms of the archaeological site spatial organization, it can be inferred that the sector III and surrounding areas present a more favorable context for the occurrence of bone diagenesis than sectors XI and XXXIV and their respective surroundings. Thus, bone samples from other individuals possibly found in sector III must present CI, IR-SF and C/P values that indicate such extensive changes as found in samples $15 \mathrm{~A}$ and $15 \mathrm{~B}$.

\section{CONCLUSIONS}

The results of this random sampling analysis point to the conclusion that the diagenetic processes changed both bone components. However, the organic was noticeably the most affected, as expected. On the other hand, the inorganic component of some samples, such as $15 \mathrm{~A}$ and $15 \mathrm{~B}$, also shown to have suffered extensive diagenetic (recrystallization) processes.

The diagenetic indices IR-SF, C/P ratio and CI are reliable and can be correlated with each other, as well as the $\mathrm{pH}$ values obtained for the sedimentary samples. However, none of the diagenetic indices directly returns information about the persistence or not of bone collagen, although it is possible to infer that from their respective interpretations. Thus, it seems that the only way to directly obtain such information is by visual comparing Amide I peaks in modern and archaeological bone FTIR-ATR spectra.

The occurrence of hydrolysis seems not to have been the main cause of bone collagen loss. Undoubtedly, the action of a slightly acidic hydrolysis can lead to collagen loss, and even strongly alkaline may cause long-term complete dissolution of the inorganic component. However, these processes necessarily depend on an almost constant presence of water in the sediment, something that, as can be seen from the introduction of this work, has become increasingly rare over the last 10,000 years in the region in which the archaeological site is located. Thus, in this case the hydrolysis appears to have produced only initial changes that facilitated the microorganisms' actions in the soil. It is important to note that this conclusion makes sense only if the $\mathrm{pH}$ values obtained for the sedimentary samples has been regular over the last few millennia, something that does not necessarily happened, obviously. Most likely the main responsibility for the absence of bone collagen were in fact the microorganisms present in the soil. The proximity to $\mathrm{pH}$ neutrality, noticeable in all but one of the sedimentary samples analyzed, denounces the existence of an environment that favors an intense microbial activity — even the slightly acid sample 1389 may have become this way as a result of this intense activity.

\section{Acknowledgments}

The authors thank INCT-INAPAS (Instituto Nacional de Ciência e Tecnologia de Arqueologia, Paleontologia e Ambiente do Semiárido do Nordeste do Brasil) for the scientific and technical support; and both Dr. Orangel Aguilera and the anonymous reviewer for the valuable contributions to this manuscript. 


\section{REFERENCES}

ABDEL-MAKSOUD, Gomaa. Comparison between the properties of accelerated-aged bones and archaeological bones. Mediterranean Archaeology and Archaeometry, v. 10, n. 1, p. 89-112, 2010.

AMBROSE, Stanley; KRIGBAUM, John. Bone chemistry and bioarchaeology. Journal of Anthropological Archaeology, v. 22, p. 193-199, 2003.

ANTHONY, John; BIDEAUX, Richard; BLADH, Kenneth; NICHOLS, Monte (eds.). Handbook of Mineralogy. Chantilly: Mineralogical Society of America, 2003.

BEASLEY, Melanie; BARTELINK, Eric; TAYLOR, Lacy; MILLER, Randy. Comparison of transmission FTIR, ATR, and DRIFT spectra: implications for assessment of bone bioapatite diagenesis. Journal of Archaeological Science, 15 , p. 16-22, 2014.

BERNA, Francesco; MATTHEWS, Alan; WEINER, Stephen. Solubilities of bone mineral from archaeological sites: the recrystallization window. Journal of Archaeological Science, v. 31, n. 7, p. 867-882, 2004.

BINFORD, Lewis. Bones: ancient men and modern myths. Orlando: Academic Press, Inc., 1981.

BORGES, CLÁUDIA. Uma narrativa pré-histórica: o cotidiano de antigos grupos humanos no sertão do Seridó/RN. (Tese) Faculdade de Ciências e Letras de Assis, Universidade Estadual de São Paulo, Assis, 2008.

BRADY, Allyson; WHITE, Christine; LONGSTAFFE, Fred; SOUTHAM, Gordon. Investigating intra-bone isotopic variations in bioapatite using IR-laser ablation and micromilling: Implications for identifying diagenesis? Palaeogeography, Palaeoclimatology, Palaeoecology, v. 266, p. 190-199, 2008.

BROCK, Fiona; HIGHAM, Tom; BRONK RAMSEY, Christopher. Pre-screening techniques for identification of samples suitable for radiocarbon dating of poorly preserved bones. Journal of Archaeological Science, v. 37, n. 4, p. 855-865, 2010.

BROWN, Terry; BROWN, Keri. Biomolecular Archaeology: An Introduction. Chichester: John Wiley \& Sons, 2011.

CECCANTI, B.; LANDI, A.; BARTOLI, F.; MALLEGNI, F.; MASCIANDARO, G.; CARMIGNANI, A.; MACCI, C. Study and control of the geochemical processes responsible of diagenetic alteration of archaeological bones. Atti Soc. tosc. Sci. nat., Mem., Serie A, v. 112, Toscana, p. 61-68, 2007.

COLLINS, Matthew; NIELSEN-MARSH, Christina; HILLER, Jennifer; SMITH, Colin; Roberts, J.P.; PRIGODICH, Richard; WESS, T.J.; CSAPÒ, J.; MILLARD, A.R.; TURNER-WALKER, Gordon. The survival of organic matter in bone: a review. Archaeometry, v. 44, n. 3, Oxford, p. 383-394, 2002.

COLONESE, André; COLLINS, Matthew; LUCQUIN, Alexandre; EUSTACE, Michael; HANCOCK, Y.; PONZONI, Raquel; MORA, Alice; SMITH, Colin; DEBLASIS, Paulo; FIGUTI, Levy; WESOLOWSKI, Veronica; PLENS, Claudia; EGGERS, Sabine; FARIAS, Deise; GLEDHILL, Andy; CRAIG, Oliver. Long-Term Resilience of Late Holocene Coastal Subsistence System in Southeastern South America. PLoS ONE, v. 9, n. 4, p. e93854, 2014.

FARIAS, ALLYSON. Diagênese óssea em ambiente semiárido brasileiro: modelagem e experimentações com sedimentos do sítio Pedra do Alexandre. (Dissertação) Programa de Pós-Graduação em Arqueologia. Universidade Federal de Pernambuco, Recife, 2013.

FARLOW, James; ARGAST, Anne. Preservation of fossil bone from the Pipe Creek Sinkhole (Late Neogene, Grant County, Indiana, U.S.A.). J. Paleont. Soc. Korea., v. 22, n. 1, Seul, p. 51-75, 2006.

GARRISON, Ervan. Techniques in Archaeological Geology. New York: Springer, 2003. 
GOFFER, Zvi. Archaeological Chemistry. Hoboken: John Wiley \& Sons, Inc., 2007.

HARBECK, Michaela; GRUPE, Gisela. Experimental chemical degradation compared to natural diagenetic alteration of collagen: implications for collagen quality indicators for stable isotope analysis. Archaeology and Anthropology Science, v. 1, p. 43-57, 2009.

HEDGES, Robert; MILLARD, Andrew; PIKE, A.W.G. Measurements and relationships of diagenetic alteration of bone from three archaeological sites. Journal of Archaeological Science, v. 22, p. 201-209, 1995.

HEDGES, Robert. Bone diagenesis: an overview of processes. Archaeometry, n. 44, v. 3, Oxford, p. 319-328, 2002.

HOLLUND, H.I.; ARIESE, F.; FERNANDES, R.; JANS, M.M.E.; KARS, H. Testing an alternative high-throughput tool for investigating bone diagenesis: FTIR in attenuated total reflection (ATR) mode. Archaeometry, v. 55, n. 3, Oxford, p. $507-532,2012$.

KENNAN, Sarah. From bone to fossil: A review of the diagenesis of bioapatite. American Mineralogist 101, p. 1943-1951, 2016.

KOCH, Paul; TUROSS, Noreen; FOGEL, Marilyn. The Effects of Sample Treatment and Diagenesis on the Isotopic Integrity of Carbonate in Biogenic Hydroxylapatite. Journal of Archaeological Science, v. 24, p. 417-429, 1997.

LAGE, Maria; FABRIS, José; MORAES, Beneilde, CAVALCANTE, Luis. Análise Química de Sedimentos como indicador de ocupação humana pré-histórica no Parque Nacional Serra da Capivara. Clio Arqueológica, v. 20, Recife, p. 103$122,2006$.

LAGE, Maria; CAVALCANTE, Luis; SANTOS, Juvandi. Estudo Químico de sedimentos arqueológicos do Parque Nacional Serra da Capivara. FUMDHAMentos, v. 6, São Raimundo Nonato, p. 106-114, 2007.

MACEDO, Helder. Pesquisas arqueológicas realizadas em Carnaúba dos Dantas, sertão do Seridó: um balanço. Semana de Humanidades 17, Natal, p. 1-39, 2009.

MAFRA, Fábio; MARTIN, Gabriela; NOGUEIRA, Mônica. Intervenções arqueológicas em sítios a céu aberto na Área Arqueológica do Seridó: os sítios Meggers I e Meggers III - Parelhas - RN, BRASIL. Clio Arqueológica, v. 30, n. 1, Recife, p. 10-37, 2015.

MARTIN, Gabriela. O Cemitério Pré-Histórico "Pedra do Alexandre” em Carnaúba dos Dantas, RN. Clio Arqueológica, v. 11, Recife, p. 43-57, 1995/1996.

MARTIN, Gabriela. Fronteiras estilísticas e culturais na Arte Rupestre do Seridó RN. Clio Arqueológica, v. 15, n. 1, Recife, p. 11-32, 2003.

MARTIN, Gabriela. Pré-História do Nordeste do Brasil. Recife: Editora Universitária da UFPE, 2008.

MARTIN, Gabriela; BORGES, Fábio; SENA, Vivian; SALDANHA, Rafael; ALMEIDA, Marcellus; NOGUEIRA, Mônica; BARBOSA, Caio. Levantamento arqueológico da área arqueológica do Seridó - Rio Grande do Norte - Brasil: Nota Prévia. Clio Arqueológica, v. 23, n. 2, Recife, p. 1-18, 2008.

MAYS, Simon. The archaeology of human bones. London: Routledge, 1988.

MUTZENBERG, DEMÉTRIO. Gênese e ocupação pré-histórica do Sítio Arqueológico Pedra do Alexandre: uma abordagem a partir da caracterização paleoambiental do Vale do Rio Carnaúba-RN. (Dissertação) Programa de Pós-Graduação em Arqueologia, Universidade Federal de Pernambuco, Recife, 2007.

PATE, F.D.; HUTON, John. The use of soil chemistry data to address post-mortem diagenesis in bone mineral. Journal of Archeological Science, v. 15, n. 6, p. 729-739, 1988. 
PATE, F.D.; HUTON, John; NORRISH, Keith. Ionic exchange between soil solution and bone: toward a predictive model. Applied Geochemistry, n. 4, v. 3, Great Britain, p. 303-316, 1989.

PIGA, Giampaolo; THOMPSON, Tim; MALGOSA, Assumpciò; ENZO, Stefano. The Potential of X-Ray Diffraction in the Analysis of Burned Remains from Forensic Contexts. Journal of Forensic Science, v. 54, n. 3, p. 534-539, 2009.

PRUVOST, Mélanie; SCHWARZ, Reinhard; CORREIA, Virginia; CHAMPLOT, Sophie; BRAGUIER, Séverine; MOREL, Nicolas; FERNANDEZ-JALVO, Yolanda; GRANGE, Thierry; GEIGL, Eva-Maria. Freshly excavated fossil bones are best for amplification of ancient DNA. Proceedings of the National Academy of Sciences, v. 104, n. 3, Washington, p. 739-744, 2007.

QUEIROZ, Albérico. Fauna de vertebrados do sítio arqueológico Pedra do Alexandre, Carnaúba dos Dantas, RN, Brasil: Uma abordagem zooarqueológica e tafonômica. Clio Arqueológica, v. 15, Recife, p. 267-282, 2002.

QUEIROZ, Albérico; CARDOSO, Glória. Nota Prévia Sobre a Fauna Holocênica de Vertebrados do Sítio Arqueológico Pedra do Alexandre, Carnaúba dos Dantas-RN, Brasil. Clio Arqueológica, v. 11, Recife, p. 137-140, 1995/1996.

REICHE, I.; VIGNAUD, C.; MENU, M. The crystallinity of ancient bone and dentine: new insights by transmission electron microscopy. Archaeometry, v. 44, n. 3, Oxford, p. 447-459, 2002.

ROBERTS, S.J.; SMITH, Colin; MILLARD, Andrew; COLLINS, Matthew. The taphonomy of cooked bone: characterising boiling and its physico-chemical effects. Archaeometry, v. 44, n. 3, Oxford, p. 485-494, 2002.

ROGERS, Keith; BECKETT, Sophie; KUHN, Samira; CHAMBERLAIN, Andrew, CLEMENT, John. Contrasting the crystallinity indicators of heated and diagenetically altered bone mineral. Palaeogeography, Palaeoclimatology, Palaeoecology, v. 296, n. 1-2, p. 125-129, 2010.

SHAHACK-GROSS, Ruth; MARSHALL, Fiona; WEINER, Steve. Geo-Ethnoarchaeology of Pastoral Sites: The Identification of Livestock Enclosures in Abandoned Maasai Settlements. Journal of Archaeological Science, v. 30, n. 4, p. 439-459, 2003.

SHAHACK-GROSS, Ruth; BERNA, Francesco, KARKANAS, Panagiotis; WEINER, Steve. Bat guano and preservation of archaeological remains in cave sites. Journal of Archaeological Science, v. 31, n. 9, p. 1259-1272, 2004.

SMITH, Colin; CRAIG, O.E.; PRIGODICH, Richard; NIELSEN-MARSH, Christina; JANS, M.M.E.; VERMEER, C.; COLLINS, Matthew. Diagenesis and survival of osteocalcin in archaeological bone. Journal of Archaeological Science, v. 32, n. 1, p. 105-113, 2005.

STATHOPOULOU, Elizabeth; PSYCHARIS, Vassilis; CHRYSSIKOS, Georgios; GIONIS, Vassilis; THEODOROU, George. Bone diagenesis: New data from infrared spectroscopy and X-ray diffraction. Palaeogeography, Palaeoclimatology, Palaeoecology, v. 266, n. 3-4, p. 168-174, 2008.

STINER, Mary; KUHN, Steven; WEINER, Stephen; BAR-YOSEF, Ofer. Differential burning, recrystallization, and fragmentation of archaeological bone. Journal of Archaeological Science, v. 22, n. 2, p. 223-237, 1995.

SUI, Tan; SANDHOLZER, Michael; BAIMPAS, Nikolaos; LANDINI, Gabriel; WALMSLEY, A.D.; LUMLEY, Philip; KORSUNSKY, Alexander. Ultrastructural Changes in Burnt Dental Tissue Revealed by Synchrotron X-ray Scattering. Proceedings of the International MultiConference of Engineers and Computer Scientists 2013, v. 2, Hong Kong, p. 775-779, 2013.

SUROVELL, Todd; STINER, Mary. Standardizing Infra-red Measures of Bone Mineral Crystallinity: an Experimental Approach. Journal of Archaeological Science, v. 28, p. 633-642, 2001. 
SZOSTEK, Krzysztof. Chemical signals and reconstruction of life strategies from ancient human bones and teeth - problems and perspectives. Anthropological Review, v. 72, p. 3-30, 2009.

THOMPSON, T.J.U.; GAUTHIER, Marie; ISLAM, Meez. The application of a new method of Fourier Transform Infrared Spectroscopy to the analysis of burned bone. Journal of Archaeological Science, v. 36, n. 3, p. 910-914, 2009.

TORRES, Ana. Estudo dos Pigmentos do Sítio Pré-Histórico Pedra do Alexandre, Carnaúba dos Dantas, RN. Clio Arqueológica, v. 11, Recife, p. 61-70, 1995/1996.

USDA Natural Resources Conservation Service. Soil Quality Information Sheet - Soil Quality Indicators: pH. Washington: USDA Natural Resources Conservation Service, 1998.

WEINER, Stephen. Microarchaeology: beyond the visible archaeological record. Cambridge: Cambridge Press, 2010.

WEINER, Stephen; BAR-YOSEF, Ofer. States of preservation of bones from prehistoric sites in the Near East: a survey. Journal of Archaeological Science, v. 17, p. 187-196, 1990.

ZAZZO, Antoine; SALIÈGE, Jean-François. Radiocarbon dating of biological apatites: A review. Palaeogeography, Palaeoclimatology, Palaeoecology, v. 310, p. 52-61, 2011.

ZAZZO, Antoine; SALIÈGE, Jean-François; LEBON, Matthieu; LEPETZ, Sébastien; MOREAU, Christophe. Radiocarbon dating of calcined bones: insights from combustion experiments under natural conditions. Radiocarbon, v. 54, n. 3-4, Tucson, p. 855-866, 2012.

Recebido em: 20/01/2018

Aprovado em: 10/04/2018

Publicado em: 30/11/2018 